SILVA, Bruna Marques da. Discursos intolerantes (ou discursos de ódio?) de parlamentares contra grupos sociais minoritários no Brasil. Revista Eletrônica Direito e Política, Programa de PósGraduação Stricto Sensu em Ciência Jurídica da UNIVALI, Itajaí, v.15, n.3, 30 quadrimestre de 2020. Disponível em: www.univali.br/direitoepolitica - ISSN 1980-7791

\title{
DISCURSOS INTOLERANTES (OU DISCURSOS DE ÓDIO?) DE PARLAMENTARES CONTRA GRUPOS SOCIAIS MINORITÁRIOS NO BRASIL
}

\author{
INTOLERABLE SPEECHES (OR HATE SPEECHES?) BY PARLIAMENTARIAN \\ AGAINST MINORITY SOCIAL GROUPS IN BRAZIL
}

Bruna Marques da Silva ${ }^{1}$

\section{RESUMO}

Este estudo objetiva investigar se e como discursos intolerantes proferidos por parlamentares contra grupos sociais minoritários estão sendo enfrentados juridicamente no Brasil. Além disso, analisar se a definição de discurso de ódio referida pela Organização das Nações Unidas para a Educação, a Ciência e a Cultura (UNESCO) aproxima-se das manifestações objetos de demanda judicial. A pesquisa é de cunho exploratório, com levantamento bibliográfico e documental, bem como empírico, com análise de jurisprudência do Supremo Tribunal Federal. Os principais resultados da pesquisa apontam que: a) discursos intolerantes proferidos por parlamentares contra grupos sociais minoritários estão sendo judicializadas; b) nesses casos, o alcance da garantia da imunidade parlamentar material permanece conectado ao exercício da função parlamentar e c) por fim, os discursos intolerantes analisados tendem a aproximar-se do conceito jurídico de discurso de ódio referido pela Organização das Nações Unidas para a Educação, a Ciência e a Cultura (UNESCO);

PALAVRAS-CHAVE: Direito à liberdade de expressão; Imunidade parlamentar; Discurso de ódio; Grupos sociais minoritários.

\section{ABSTRACT}

This article investigates whether and how intolerant speeches by parliamentarians against minority social groups are being approached legal in Brazil. In addition, it analyze whether the definition of hate speech referred to by the United Nations Educational, Scientific and Cultural Organization (UNESCO) similar the speeches of cases law analysed. The research is exploratory, with bibliographic and documentary review and jurisprudence review of the Federal Supreme Court. The results indicates that: a) intolerant speeches by parliamentarians against minority social groups are being judicial approach; $b$ ) in theses cases, the constitucional guarantee of material parliamentary immunity remains connected to the exercise of the parliamentary function and c) finally,

\footnotetext{
1 Mestranda em Direito pelo Programa de Pós-Graduação em Direito da Universidade do Vale do Rio dos Sinos - Unisinos, São Leopoldo, Brasil. Bolsista CNPq. Advogada. Integrante do Núcleo de Direitos Humanos da Unisinos, coordenado pela Profa. Dra. Fernanda Frizzo Bragato. Endereço eletrônico: bmrqs@outlook.com.
} 
SILVA, Bruna Marques da. Discursos intolerantes (ou discursos de ódio?) de parlamentares contra grupos sociais minoritários no Brasil. Revista Eletrônica Direito e Política, Programa de PósGraduação Stricto Sensu em Ciência Jurídica da UNIVALI, Itajaí, v.15, n.3, 30 quadrimestre de 2020. Disponível em: www.univali.br/direitoepolitica - ISSN 1980-7791

the intolerant speeches analyzed tend to similar the legal concept of hate speech referred to by the United Nations Educational Organization, Science and Culture (UNESCO);

KEYWORDS: Right to freedom of expression; Parliamentary immunity; Hate speech; Minority social groups.

\section{INTRODUÇÃO}

Discursos de ódio, de modo geral, são descritos como manifestações que insultam grupos ou indivíduos com base em características de pertencimento a uma coletividade, ou incitam à hostilidade, discriminação e violência. Esta temática, problematizada à luz dos limites ao exercício do direito à liberdade de expressão, apresenta-se de forma complexa ao âmbito jurídico internacional e nacional. No Brasil, indivíduos que exercem a função parlamentar, e fazem jus à prerrogativa da imunidade parlamentar material, têm manifestado discursos intolerantes contra grupos sociais considerados minoritários no sentido qualitativo. Nesse aspecto, há, portanto, uma tensão não apenas relativa aos limites e verificação do alcance da garantia constitucional e à liberdade de expressão, mas na identificação se tais discursos poderiam ser considerados de ódio ou não.

A partir dessas premissas, este estudo objetiva investigar se e como discursos intolerantes proferidos por parlamentares contra grupos sociais minoritários estão sendo enfrentados juridicamente no Brasil. Além disso, analisar se a definição de discurso de ódio referida pela Organização das Nações Unidas para a Educação, a Ciência e a Cultura (UNESCO) aproxima-se das manifestações objetos de demanda judicial. A pretensão de tais abordagens justifica-se pelo fato de que o direito internacional dos direitos humanos tem registrado preocupação com discursos de ódio proferidos por representantes da população no poder público. Além disso, porque não há um conceito jurídico universalmente aceito para definir juridicamente discurso de ódio. $O$ entendimento adotado neste estudo para discurso de ódio, segundo a UNESCO, abrange a maioria das definições sobre o fenômeno.

A pesquisa, de cunho exploratório, com levantamento bibliográfico e documental, bem como empírico, com análise de jurisprudência do Supremo Tribunal Federal, 
SILVA, Bruna Marques da. Discursos intolerantes (ou discursos de ódio?) de parlamentares contra grupos sociais minoritários no Brasil. Revista Eletrônica Direito e Política, Programa de PósGraduação Stricto Sensu em Ciência Jurídica da UNIVALI, Itajaí, v.15, n.3, 30 quadrimestre de 2020. Disponível em: www.univali.br/direitoepolitica - ISSN 1980-7791

divide-se em três momentos. Primeiramente, será analisado o direito à liberdade de expressão e a imunidade parlamentar material. Após, serão registradas investigações sobre discursos de ódio no contexto parlamentar. Ao final, será realizada análise jurisprudencial de casos de discursos intolerantes manifestados por parlamentares contra grupos minoritários levados ao Supremo Tribunal Federal, que permitem apontar de forma afirmativa que tais discursos estão sendo enfrentados pelo poder judiciário e que, nesses casos, o alcance da garantia da imunidade parlamentar material permanece conectado ao exercício da função parlamentar. Além disso, que os discursos analisados tendem a aproximar-se do conceito jurídico de discurso de ódio referido pela Organização das Nações Unidas para a Educação, a Ciência e a Cultura (UNESCO).

\section{DIREITO À LIBERDADE DE EXPRESSÃO E IMUNIDADE PARLAMENTAR MATERIAL: ALCANCES DA GARANTIA CONSTITUCIONAL}

No Brasil, assim como em outros países, a liberdade de expressão constitui-se como um direito essencial ao Estado Democrático de Direito. Ao consolidar o processo de redemocratização e objetivando deslegitimar a censura autorizada durante o período da ditadura civil-militar, a Constituição Federal de 1988 estabeleceu primazia à proteção do direito à liberdade de expressão, consolidando-o como instrumento para a proteção do pluralismo de ideias e da democracia. ${ }^{2}$ Na legislação constitucional, o artigo $5^{\circ}$ e incisos VI, V, IX, XVI, XLI e XLII, consagram a dupla dimensão deste direito e, ainda, seu caráter não absoluto. $^{3}$ Esta última característica, abrange cada vez mais questões complexas ligadas às possíveis limitações do exercício do direito à liberdade de expressão, a exemplo dos chamados discursos de ódio, ou hate speech, termo comumente utilizado na doutrina estrangeira e brasileira ${ }^{4}$.

Segundo Soares, o direito à liberdade de expressão, por garantir a expressão de ideias e pensamentos, possibilita que o indivíduo também se posicione de forma

\footnotetext{
2 SARMENTO, Daniel. A liberdade de expressão e o problema do "Hate Speech". In: SARMENTO, Daniel. Livres e iguais: estudos de Direito Constitucional. Rio de Janeiro: Lumen Juris, 2006.

3 BRASIL. Constituição da República Federativa do Brasil de 1988. Disponível em: <http://www.planalto.gov.br/ccivil_03/constituicao/constituicao.htm>. Acesso em: 14 ago. 2019.

${ }^{4}$ SARMENTO, Daniel. A liberdade de expressão e o problema do "Hate Speech". In: SARMENTO, Daniel. Livres e iguais: estudos de Direito Constitucional. Rio de Janeiro: Lumen Juris, 2006.
} 
SILVA, Bruna Marques da. Discursos intolerantes (ou discursos de ódio?) de parlamentares contra grupos sociais minoritários no Brasil. Revista Eletrônica Direito e Política, Programa de PósGraduação Stricto Sensu em Ciência Jurídica da UNIVALI, Itajaí, v.15, n.3, 30 quadrimestre de 2020. Disponível em: www.univali.br/direitoepolitica - ISSN 1980-7791

livre em relação à temas de interesse público: "[...] alguns cidadãos podem, por exemplo, manifestar-se a favor da adoção da pena de morte, outros contra; alguns podem tomar posição pela redução da idade de menoridade penal e outros simplesmente a objetarem [... $]^{\prime{ }^{5}}$ Isso significa dizer que o exercício do direito à liberdade de expressão, sob o contexto constitucional, tutela inclusive a oposição pessoal do indivíduo a políticas públicas ou garantias já tuteladas pelo ordenamento jurídico internacional e brasileiro. A discordância sobre pautas que tocam o âmbito político, jurídico e social, nesse sentido, são consideradas legítimas e abrangidas pelo pluralismo que também fundamenta o sistema democrático.

No contexto dessa característica específica, o caráter não absoluto do direito à liberdade de expressão apresenta certa exceção legal destinada aos indivíduos que exercem mandatos populares na Câmara dos Deputados e no Senado Federal. ${ }^{6}$ Essa exceção é garantida por prerrogativas inerentes à função e exercício do cargo de parlamentar, concedendo aos indivíduos que o exercem máxima amplitude no exercício da liberdade de expressão. Assim, a Constituição Federal, nos artigos 53 a 56, estabelece regramentos especiais que se destinam a Deputados Federais, Estaduais, Distritais, bem como a Senadores e Vereadores, concedendo-Ihes prerrogativas constitucionais nomeadas como imunidades, com fim de "[...] assegurar a liberdade do representante do povo ou do Estado-membro no Congresso Nacional, como garantia da independência do próprio parlamento e da sua existência." ${ }^{7}$

Segundo Mendes, as imunidades classificam-se entre material e formal e correspondem a: "A imunidade pode tornar o parlamentar insuscetível de ser punido por certos fatos (imunidade material) ou livre de certos constrangimentos

\footnotetext{
${ }^{5}$ SOARES, Alessandro. Direitos humanos e decoro parlamentar: sobre a possibilidade de cassação de mandato por discurso de ódio. Revista DIREITO UFMS. v3. n.2 jul./dez, p. 123-152, Mato Grosso do Sul, 2017. p. 131.

${ }^{6}$ MENDES, Gilmar Ferreira. II - Administração Pública. In: MENDES, Gilmar Ferreira; BRANCO, Paulo Gustavo Gonet. (Org.). Curso de Direito Constitucional. 12 ed. rev. e atual. São Paulo: Saraiva, 2017.

7 MENDES, Gilmar Ferreira. II - Administração Pública. In: MENDES, Gilmar Ferreira; BRANCO, Paulo Gustavo Gonet. (Org.). Curso de Direito Constitucional. 12 ed. rev. e atual. São Paulo: Saraiva, 2017. p. 969.
} 
SILVA, Bruna Marques da. Discursos intolerantes (ou discursos de ódio?) de parlamentares contra grupos sociais minoritários no Brasil. Revista Eletrônica Direito e Política, Programa de PósGraduação Stricto Sensu em Ciência Jurídica da UNIVALI, Itajaí, v.15, n.3, 30 quadrimestre de 2020. Disponível em: www.univali.br/direitoepolitica - ISSN 1980-7791

previstos no ordenamento processual penal (imunidade formal). ${ }^{8}$ Desse modo, a imunidade que toca especificamente o direito à liberdade de expressão é a disposta no artigo 53, tratando-se de uma imunidade de ordem material. Da leitura do artigo referido, a imunidade material consiste na inviolabilidade do parlamentar, no âmbito civil e penal, pela expressão de quaisquer opiniões, palavras e votos. ${ }^{9}$ Há, portanto, a isenção de responsabilidade civil ou penal ao congressista pelo exercício de sua liberdade de expressão, no exercício ou em razão do mandato. O parlamentar, nesse sentido, não poderá responder juridicamente por perdas e danos e nem terá seus atos constituídos como crimes. $^{10}$

Contudo, esta garantia não se propôs a constituir-se como um benefício pessoal do congressista por suas expressões, mas como uma proteção ao desempenho de sua função, uma vez que se origina através do cargo exercido, aplicando-se no desempenho deste e desde que as manifestações sejam exercidas em conexão com o mandato. ${ }^{11}$ Nesse sentido, considerando os três posicionamentos que a doutrina brasileira adota quanto às imunidades, Streck, Oliveira e Nunes afirmam que o Supremo Tribunal Federal parece ter optado pela posição moderada à ultracorporativista e extremista, por entender que a imunidade material não alcança a responsabilidade civil do parlamentar no caso de: a) danos que possam ser causados por suas manifestações; b) por ofensas desconectadas da função ou do exercício do cargo $^{12}$.

\footnotetext{
8 MENDES, Gilmar Ferreira. II - Administração Pública. In: MENDES, Gilmar Ferreira; BRANCO, Paulo Gustavo Gonet. (Org.). Curso de Direito Constitucional. 12 ed. rev. e atual. São Paulo: Saraiva, 2017. p. 969.

9 BRASIL. Constituição da República Federativa do Brasil de 1988. Disponível em: <http://www.planalto.gov.br/ccivil_03/constituicao/constituicao.htm>. Acesso em: 14 ago. 2019.

${ }^{10}$ STRECK, Lênio Luiz; OLIVEIRA, Marcelo Andrade Cattoni de Oliveira; NUNES, Dierli. Seção V. dos Deputados e dos Senadores. Art. 53 - Os deputados e Senadores são invioláveis, civil e penalmente, por quaisquer de suas opiniões, palavras e votos. In: CANOTLHO, J.J. Gomes; MENDES, Gilmar Ferreira; SARLET, Ingo Wolfgang. STRECK, Lênio Luiz (coord.). Comentários à Constituição Federal do Brasil. São Paulo: Saraiva/Almedina, 2013.
}

${ }^{11}$ STRECK, Lênio Luiz; OLIVEIRA, Marcelo Andrade Cattoni de Oliveira; NUNES, Dierli. Seção V. dos Deputados e dos Senadores. Art. 53 - Os deputados e Senadores são invioláveis, civil e penalmente, por quaisquer de suas opiniões, palavras e votos. In: CANOTLHO, J.J. Gomes; MENDES, Gilmar Ferreira; SARLET, Ingo Wolfgang. STRECK, Lênio Luiz (coord.). Comentários à Constituição Federal do Brasil. São Paulo: Saraiva/Almedina, 2013.

${ }^{12}$ STRECK, Lênio Luiz; OLIVEIRA, Marcelo Andrade Cattoni de Oliveira; NUNES, Dierli. Seção V. dos Deputados e dos Senadores. Art. 53 - Os deputados e Senadores são invioláveis, civil e penalmente, por quaisquer de suas opiniões, palavras e votos. In: CANOTLHO, J.J. Gomes; 
SILVA, Bruna Marques da. Discursos intolerantes (ou discursos de ódio?) de parlamentares contra grupos sociais minoritários no Brasil. Revista Eletrônica Direito e Política, Programa de PósGraduação Stricto Sensu em Ciência Jurídica da UNIVALI, Itajaí, v.15, n.3, 30 quadrimestre de 2020. Disponível em: www.univali.br/direitoepolitica - ISSN 1980-7791

Assim, afirma que "Não se comprovando o nexo entre as manifestações proferidas e o cumprimento do mandato legislativo, não será o parlamentar protegido pela imunidade, podendo, então, ser responsabilizado." ${ }^{13}$. Isso porque não é possível que a imunidade seja utilizada como um respaldo para que o indivíduo exerça sua liberdade de expressão em desconexão com o mandato, o que contrariaria a própria democracia. Nesse sentido:

Seria uma contradição que, em nome da democracia e da garantia da liberdade do exercício do mandato, viéssemos a entender que o parlamentar é uma pessoa acima da lei, podendo 'dizer qualquer coisa' e invocar a proteção da expressão semântica 'quaisquer de suas opiniões, palavras ou votos'. Também não bastará a simples invocação de estar proferindo determinadas opiniões 'no exercício do mandato'. Essa conexão deve estar demonstrada à sociedade, nos mínimos detalhes, para evitar abusos e impunidades. ${ }^{14}$

Paulino, entretanto, chama atenção ao fato de que em razão da disposição do artigo 53 da Constituição Federal não condicionar expressamente a inviolabilidade parlamentar ao exercício da função ou em razão desta, a legislação constitucional não indica claramente qual deve ser o tratamento jurídico a expressões referidas fora do recinto do Congresso Nacional ou nas suas dependências. Estas questões, assim como à atinente ao não alcance da imunidade à ocorrência de danos e expressões ofensivas que não apresentam conexão com o mandato, já foram objeto de enfrentamento pelo Supremo Tribunal Federal, e, portanto, o entendimento jurisprudencial pode oferecer certos esclarecimentos ${ }^{15}$.

MENDES, Gilmar Ferreira; SARLET, Ingo Wolfgang. STRECK, Lênio Luiz (coord.). Comentários à Constituição Federal do Brasil. São Paulo: Saraiva/Almedina, 2013.

${ }^{13}$ STRECK, Lênio Luiz; OLIVEIRA, Marcelo Andrade Cattoni de Oliveira; NUNES, Dierli. Seção V. dos Deputados e dos Senadores. Art. 53 - Os deputados e Senadores são invioláveis, civil e penalmente, por quaisquer de suas opiniões, palavras e votos. In: CANOTLHO, J.J. Gomes; MENDES, Gilmar Ferreira; SARLET, Ingo Wolfgang. STRECK, Lênio Luiz (coord.). Comentários à Constituição Federal do Brasil. São Paulo: Saraiva/Almedina, 2013. p. 1074.

${ }^{14}$ STRECK, Lênio Luiz; OLIVEIRA, Marcelo Andrade Cattoni de Oliveira; NUNES, Dierli. Seção V. dos Deputados e dos Senadores. Art. 53 - Os deputados e Senadores são invioláveis, civil e penalmente, por quaisquer de suas opiniões, palavras e votos. In: CANOTLHO, J.J. Gomes; MENDES, Gilmar Ferreira; SARLET, Ingo Wolfgang. STRECK, Lênio Luiz (coord.). Comentários à Constituição Federal do Brasil. São Paulo: Saraiva/Almedina, 2013. p. 1074.

15 PAULINO, Lucas Azevedo. Imunidade material parlamentar, liberdade de expressão e discurso do ódio: parâmetros para o tratamento jurídico do hate speech parlamentar. In: PEREIRA, Rodolfo 
SILVA, Bruna Marques da. Discursos intolerantes (ou discursos de ódio?) de parlamentares contra grupos sociais minoritários no Brasil. Revista Eletrônica Direito e Política, Programa de PósGraduação Stricto Sensu em Ciência Jurídica da UNIVALI, Itajaí, v.15, n.3, 30 quadrimestre de 2020. Disponível em: www.univali.br/direitoepolitica - ISSN 1980-7791

Desse modo, conforme com os entendimentos jurisprudenciais reunidos por Streck, Oliveira e Nunes, de acordo com o Inquérito 1.958, se supostas ofensas forem proferidas por parlamentares dentro das Casas Legislativas, não se faz necessário demonstrar o exercício do mandato ou função deste, cabendo à própria Casa Legislativa coibir excessos à prerrogativa. De outro lado, caso a expressão tenha sido proferida fora do ambiente legislativo, para que a inviolabilidade a alcance, exige-se a comprovação do nexo de causalidade entre a manifestação e o exercício da função parlamentar; Já quanto ao Inquérito 2.390, o Supremo Tribunal Federal refere que não incidirá a imunidade quando o parlamentar proferir manifestações em entrevista a programa de televisão sem conexão com o mandato; De outro lado, no Inquérito 1.710, a imunidade material não abrange opiniões, palavras e votos em desconexão com o exercício do mandato, podendo o parlamentar responder perante o Supremo Tribunal Federal sem licença da Casa Legislativa. ${ }^{16}$

Nesta perspectiva, cabe registrar, no mais, a orientação dada pelo Informativo no 831 do Supremo Tribunal Federal, ainda no que tange ao âmbito penal. No Informativo no 831, foi arguida especificamente a situação entre incitação ao crime de estupro, injúria e imunidade parlamentar, referindo que as manifestações proferidas na Câmara dos Deputados, porém veiculadas em entrevista concedida à imprensa, não abrangeriam a inviolabilidade da imunidade, uma vez que não teriam relação com o mandato. A expressão em questão foi expressada pelo à época Deputado Federal Jair Messias Bolsonaro contra a Deputada Federal Maria do Rosário Nunes, e continham o seguinte teor: "não merece ser estuprada, por ser muito ruim, muito feia, não fazer seu gênero"; o Deputado ainda acrescentou que se fosse estuprador, "não iria estuprá-la porque ela não merece" ${ }^{17}$

Viana (Org.). Direitos políticos, liberdade de expressão e discurso de ódio. Volume I. Belo Horizonte: IDDE, 2018. p. 137-162.

${ }^{16}$ STRECK, Lênio Luiz; OLIVEIRA, Marcelo Andrade Cattoni de Oliveira; NUNES, Dierli. Seção V. dos Deputados e dos Senadores. Art. 53 - Os deputados e Senadores são invioláveis, civil e penalmente, por quaisquer de suas opiniões, palavras e votos. In: CANOTLHO, J.J. Gomes; MENDES, Gilmar Ferreira; SARLET, Ingo Wolfgang. STRECK, Lênio Luiz (coord.). Comentários à Constituição Federal do Brasil. São Paulo: Saraiva/Almedina, 2013.

17 BRASIL. Supremo Tribunal Federal. Informativo no 831 - Incitação ao crime de estupro, injúria e imunidade parlamentar. 2016. Disponível em: 
SILVA, Bruna Marques da. Discursos intolerantes (ou discursos de ódio?) de parlamentares contra grupos sociais minoritários no Brasil. Revista Eletrônica Direito e Política, Programa de PósGraduação Stricto Sensu em Ciência Jurídica da UNIVALI, Itajaí, v.15, n.3, 30 quadrimestre de 2020. Disponível em: www.univali.br/direitoepolitica - ISSN 1980-7791

O Supremo Tribunal Federal, nesse sentido, sustentou que tais afirmações não poderiam ser relacionadas ao desempenho da função do mandato ou seu exercício, pois tratava-se de opiniões meramente pessoais, "[...] sem relação com o debate democrático de fatos ou ideias e, portanto, sem vínculo com o exercício das funções cometidas a um parlamentar". ${ }^{18}$ Interessante registrar que, na oportunidade, o Supremo também referiu elementos para averiguar quais afirmações conectam-se com as funções parlamentares, aduzindo que:

[...] devem revelar teor minimamente político, referido a fatos que estejam sob debate público, sob investigação em CPI ou em órgãos de persecução penal ou, ainda, sobre qualquer tema que seja de interesse de setores da sociedade, do eleitorado, de organizações ou quaisquer grupos representados no parlamento ou com pretensão à representação democrática. ${ }^{19}$

Estes esclarecimentos jurisprudenciais do Supremo Tribunal Federal são referentes à parâmetros relativos à inviolabilidade penal pelas palavras, votos ou opiniões proferidas por parlamentares. Contudo, cabe esclarecer que a inviolabilidade civil também vem sendo questionada perante o Poder Judiciário. Exemplo disso é que este fato, que envolve o à época Deputado Federal Jair Messias Bolsonaro, foi objeto de demanda judicial civil, sob o fim de postular a condenação indenizatória do parlamentar por ofensas à Deputada Federal Maria do Rosário Nunes. Assim, o Superior Tribunal de Justiça, no REsp 642310/DF, negou o recurso especial interposto pelo Deputado Federal, mantendo a condenação e determinando a publicação de retratação em jornal de grande circulação, assim como nas páginas de suas principais redes sociais, sob pena de multa. A Ministra Nancy Andrighi manifestou-se no sentido de não considerar as manifestações abrangidas pela imunidade parlamentar, uma vez que a ofensa

<http://www.stf.jus.br/portal/informativo/verInformativo.asp?s1=imunidade\%20parlam entar\&numero $=831$ \&pagina $=12 \&$ base $=I N F O>$. Acesso em: 08 out. 2019.

18 BRASIL. Supremo Tribunal Federal. Informativo no 831 - Incitação ao crime de estupro, injúria e imunidade parlamentar. 2016. Disponível em: <http://www.stf.jus.br/portal/informativo/verInformativo.asp?s1=imunidade\%20parlam entar\&numero $=831$ \&pagina $=12 \&$ base $=I N F O>$. Acesso em: 08 out. 2019.

19 BRASIL. Supremo Tribunal Federal. Informativo no 831 - Incitação ao crime de estupro, injúria e imunidade $2016 . \quad$ Disponível em: <http://www.stf.jus.br/portal/informativo/verInformativo.asp?s1=imunidade\%20parlam entar\&numero=831\&pagina $=12 \&$ base $=$ INFO $>$. Acesso em: 08 out. 2019. 
SILVA, Bruna Marques da. Discursos intolerantes (ou discursos de ódio?) de parlamentares contra grupos sociais minoritários no Brasil. Revista Eletrônica Direito e Política, Programa de PósGraduação Stricto Sensu em Ciência Jurídica da UNIVALI, Itajaí, v.15, n.3, 30 quadrimestre de 2020. Disponível em: www.univali.br/direitoepolitica - ISSN 1980-7791

não teria qualquer relação com o mandato legislativo do recorrente. ${ }^{20}$. A decisão transitou em julgado em 27 de março de 2019.

Chama-se atenção, diante do exposto, ao aspecto elementar de que a aferição dos alcances da garantia constitucional da imunidade parlamentar material conecta-se com a necessária identificação de vinculação das manifestações com o exercício do mandato. ${ }^{21}$ Somando-se à discussão sobre liberdade de expressão e alcances da imunidade parlamentar, as normas soft law do direito internacional dos direitos humanos e a doutrina brasileira problematizam as manifestações de discursos de ódio veiculadas por funcionários públicos ${ }^{22}$ e, por extensão, por indivíduos que exercem a função parlamentar. Cabe, nesse ponto, um maior detalhamento de ambas investigações.

\section{DisCURSO DE ÓdiO NO CONTEXTO PARLAMENTAR: POSSÍveIS CARACTERIZAÇÕES E IMPLICAÇÕES JURÍDICAS}

Os entendimentos do Sistema Global e Interamericano de Proteção dos Direitos Humanos sobre discursos de ódio proferidas por funcionários públicos foram construídos, em parte, mediante interpretação de disposições contidas em tratados internacionais. Dentre eles encontram-se o Pacto Internacional de Direitos Civis e Políticos, a Convenção Americana de Direitos Humanos, e Convenção Internacional para a Combate a de Todas as Formas de Discriminação. Ambos foram devidamente ratificados pelo Brasil, o que vincula o país perante a jurisdição internacional. ${ }^{23}$

\footnotetext{
20 BRASIL. Superior Tribunal de Justiça. Recurso Especial 1642310 DF. Relatora Ministra Nancy Andrighi. Julgado no dia 15 de agosto de 2017. Disponível em: <https://ww2.stj.jus.br/processo/pesquisa/?aplicacao=processos. ea\&tipoPesquisa $=$ ti poPesquisaGenerica\&termo=REsp\%201642310>. Acesso em: 08 out. 2019.

21 BRASIL. Supremo Tribunal Federal. Informativo no 831 - Incitação ao crime de estupro, injúria e imunidade parlamentar. $2016 . \quad$ Disponível em: <http://www.stf.jus.br/portal/informativo/verInformativo.asp?s1=imunidade\%20parlam entar\&numero $=831$ \&pagina $=12 \&$ base $=I N F O>$. Acesso em: 08 out. 2019.
}

22 De acordo com os documentos internacionais pesquisados, o conceito de "funcionários públicos" abrange agentes estatais, representantes da população e demais sujeitos investidos em cargos políticos.

23 NACIONES UNIDAS, Asamblea General. Promoción y Protección del Derecho a la Libertad de Opinión $y$ de Expresión. [S.I.], 7 sept. 2012. Disponível em: <http://www.un.org/en/ga/search/view_doc.asp?symbol=a/67/357\&Lang=S> Acesso em: 15 out. 2018. NACIONES UNIDAS, Asamblea General. Comité para la Eliminación de la Discriminación 
SILVA, Bruna Marques da. Discursos intolerantes (ou discursos de ódio?) de parlamentares contra grupos sociais minoritários no Brasil. Revista Eletrônica Direito e Política, Programa de PósGraduação Stricto Sensu em Ciência Jurídica da UNIVALI, Itajaí, v.15, n.3, 30 quadrimestre de 2020. Disponível em: www.univali.br/direitoepolitica - ISSN 1980-7791

No âmbito do Sistema Global de Proteção de Direitos Humanos (ONU), o Informe do Relator das Nações Unidas, de 2012 registrou que esses indivíduos devem utilizar de sua posição social e política para denunciá-las e rechaçá-las oficialmente, a fim de impulsionar o diálogo, a tolerância e o esclarecimento de que o direito à liberdade de expressão deve ser exercido em harmonia com os demais direitos humanos protegidos. O Informe orienta, nesse sentido, que os Estados adotem medidas disciplinares para os funcionários públicos que manifestem ódio ou que o incitem ${ }^{24}$, isso porque:

Quando os altos funcionários expressam ódio, prejudicam não apenas o direito de não discriminação dos grupos afetados, mas também a confiança que tais grupos depositam nas instituições do Estado, e, com isso, a qualidade e o nível de sua participação na democracia ${ }^{25}$.

Além disso, a Recomendação no 35 do Comitê para Eliminação de Todas as Formas de Discriminação Racial, analisando a Convenção Internacional para a Combate a de Todas as Formas de Discriminação ratificada pelo Brasil, cunhou diretrizes interpretativas sobre o artigo 40, que expressamente prevê a necessidade de que os Estados adotem medidas disciplinares contra funcionários públicos ou instituições públicas que expressem manifestações de ódio. Conforme a orientação internacional, configura-se um comprometimento do

Racial. Recomendación general no 35: La lucha contra el discurso de odio racista. [S.I.], 26 sept, 2013. Disponível em: <http://www.refworld.org.es/docid/53f4596b4.html>. Acesso em: 22 ou. 2018. ORGANIZACIÓN DE LOS ESTADOS AMERICANOS (OEA). Comisión Interamericana de Derechos Humanos. Relatoría Especial para la Libertad de Expresión. Informe Anual de la Relatoria Especial para la Libertad de Expressión, 2015. Disponível em: <http://www.oas.org/es/cidh/expresion/docs/informes/anuales/informeanual2015rele. pdf> Acesso em: 10 out. 2019.

${ }^{24}$ NACIONES UNIDAS, Asamblea General. Promoción y Protección del Derecho a la Libertad de Opinión y de Expresión. [S.I.], 7 sept. 2012. Disponível em: <http://www.un.org/en/ga/search/view_doc.asp?symbol=a/67/357\&Lang=S> Acesso em: 15 out. 2018

${ }^{25}$ No original: "Cuando los altos funcionarios hacen expresión del odio, menoscaban no solo el derecho de no discriminación de los grupos afectados, sino también la confianza que tales grupos depositan en las instituciones del Estado y, con ello, la calidad y el nivel de su participación en la democracia." NACIONES UNIDAS, Asamblea General. Promoción y Protección del Derecho a la Libertad de Opinión y de Expresión. [S.I.], 7 sept. 2012. Disponível em: <http://www.un.org/en/ga/search/view_doc.asp?symbol=a/67/357\&Lang=S> Acesso em: 15 out. 2018. p. 20. 
SILVA, Bruna Marques da. Discursos intolerantes (ou discursos de ódio?) de parlamentares contra grupos sociais minoritários no Brasil. Revista Eletrônica Direito e Política, Programa de PósGraduação Stricto Sensu em Ciência Jurídica da UNIVALI, Itajaí, v.15, n.3, 30 quadrimestre de 2020. Disponível em: www.univali.br/direitoepolitica - ISSN 1980-7791

Estado não permitir que as autoridades e instituições públicas, nacionais ou locais, incitem à discriminação racial ou a encorajem. ${ }^{26}$

O Sistema Regional Interamericano de Direitos Humanos, de igual forma, sustentou que a Corte Interamericana já reconheceu que as manifestações de ódio proferidas por indivíduos que desempenham atividades estatais podem contribuir para aumentar a vulnerabilidade política e social dos indivíduos potencialmente sujeitos à violência. Isso porque a obrigação contraída pelos Estados de promover e garantir os direitos humanos implica que os funcionários púbicos, em sua condição, exerçam sua liberdade de expressão sem desprezar os demais direitos humanos. Além disso, a Comissão Interamericana citou o Brasil neste aspecto, demonstrando preocupação à fala do Deputado Federal Marco Antônio Feliciano ${ }^{27}$, considerando-a intolerante e dotada de estigmas do contra o grupo LGBTI. ${ }^{28}$

Ressalta-se, ainda, que conforme o entendimento do direito internacional dos direitos humanos, não há um conceito jurídico universalmente aceito para definir o termo discurso de ódio. ${ }^{29}$ De acordo com Weber, o Sistema Europeu de Direitos Humanos conta com um conceito definido na Recomendação no (97) do Comitê dos Ministros dos Estados-membros sobre "discurso de ódio", de 1997, do Conselho da Europa ${ }^{30}$. Na Recomendação, entende-se por discurso de ódio toda e qualquer expressão que espalhe, promova, incite ou justifique formas de ódio com base em raça, religião, anti-semitismo, nacionalismo. O conceito também ${ }^{26}$ NACIONES UNIDAS, Asamblea General. Comité para la Eliminación de la Discriminación Racial.
Recomendación general no 35 : La lucha contra el discurso de odio racista. [S.I.], 26 sept, 2013.
Disponível em: <http://www.refworld.org.es/docid/53f4596b4.html>. Acesso em: 22 ou. 2018.
${ }^{27}$ Inquérito Penal 3590/DF, que será analisado na próxima etapa deste estudo.
${ }^{28}$ ORGANIZACIÓN DE LOS ESTADOS AMERICANOS (OEA). Comisión Interamericana de Derechos
Humanos. Relatoría Especial para la Libertad de Expresión. Informe Anual de la Relatoria
Especial para la Libertad de Expressión, 2015. Disponível em:
<http://www.oas.org/es/cidh/expresion/docs/informes/anuales/informeanual2015rele. pdf>

Acesso em: 10 out. 2019.

29 ORGANIZACIÓN DE LOS ESTADOS AMERICANOS (OEA). Comisión Interamericana de Derechos Humanos. Relatoría Especial para la Libertad de Expresión. Informe Anual de la Relatoria Especial para la Libertad de Expressión, 2015. Disponível em: <http://www.oas.org/es/cidh/expresion/docs/informes/anuales/informeanual2015rele. pdf> Acesso em: 10 out. 2019; WEBER, Anne. Manual on hate speech. Concil of Europe Publishing, 2009. Disponível em: http://icm.sk/subory/Manual_on_hate_speech.pdf. Acesso em: 30 jun. 2019.

30 WEBER, Anne. Manual on hate speech. Concil of Europe Publishing, 2009. Disponível em: http://icm.sk/subory/Manual_on_hate_speech.pdf. Acesso em: 30 jun. 2019. 
SILVA, Bruna Marques da. Discursos intolerantes (ou discursos de ódio?) de parlamentares contra grupos sociais minoritários no Brasil. Revista Eletrônica Direito e Política, Programa de PósGraduação Stricto Sensu em Ciência Jurídica da UNIVALI, Itajaí, v.15, n.3, 30 quadrimestre de 2020. Disponível em: www.univali.br/direitoepolitica - ISSN 1980-7791

abrange qualquer discriminação e hostilidade contra minorias, migrantes e pessoas de origem imigrante. ${ }^{31}$

Apesar da definição não conter o fator orientação sexual, a autora refere que a Corte Europeia de Direitos Humanos também considera esse elemento nas definições de discriminação e discursos de ódio. ${ }^{32}$ Já o Sistema Interamericano de Direitos Humanos, considerando a divergência conceitual, registra o seguinte conceito definido pela Organização das Nações Unidas para a Educação, a Ciência e a Cultura (UNESCO). Esta é a definição adotada para o presente estudo ${ }^{33}$, e corresponde a:

[...] as expressões a favor da incitação de fazer dano (particularmente a discriminação, hostilidade e violência), com base na identificação da vítima como pertencente a determinado grupo social ou demográfico. Pode incluir, entre outros, discursos que incitam, ameaçam ou motivam a cometer atos de violência. Não obstante, para alguns o conceito se estende também às expressões que alimentam um ambiente de prejuízo e intolerância no entendimento de que tal ambiente pode incentivar a discriminação, hostilidade e ataques violentos dirigidos a certas pessoas. ${ }^{34}$

No mais, de acordo com a doutrina brasileira, para Soares, o discurso de ódio pode ser considerado como uma atitude não democrática, haja vista que

31 COUNCIL OF EUROPE. Committee of Ministers. Recommendation $\mathbf{n}^{\mathbf{0}}$ (97) 20 of the Committee of Ministers to Member States on "Hate Speech". 1997. Disponível em: https://rm.coe.int/CoERMPublicCommonSearchServices/DisplayDCTMContent?documentId =090000 1680505d5b. Acesso em: 30 jun. 2019.

32 WEBER, Anne. Manual on hate speech. Concil of Europe Publishing, 2009. Disponível em: http://icm.sk/subory/Manual_on_hate_speech.pdf. Acesso em: 30 jun. 2019.

33 Este conceito é adotado para o presente. Segundo a UNESCO, tal definição contempla a maioria das definições sobre discurso de ódio. UNITED NATIONS EDUCATIONAL, SCIENTIFIC AND CULTURAL ORGANIZATION (UNESCO). Countering online hate speech. Iginio Gagliardone. Danit Gal. Thiago Alves. Gabriela Martinez. France: UNESCO, 2015. Disponível em: https://unesdoc.unesco.org/ark:/48223/pf0000233231. Acesso em: 04 ago. 2019.

34 No original: "[...] las expresiones a favor de la incitación a hacer daño (particularmente a la discriminación, hostilidad o violencia) con base en la identificación de la víctima como perteneciente a determinado grupo social o demográfico. Puede incluir, entre otros, discursos que incitan, amenazan o motivan a cometer actos de violencia. No obstante, para algunos el concepto se extiende también a las expresiones que alimentan un ambiente de prejuicio y intolerancia en el entendido de que tal ambiente puede incentivar la discriminación, hostilidad y ataques violentos dirigidos a ciertas personas." ORGANIZACIÓN DE LOS ESTADOS AMERICANOS (OEA). Comisión Interamericana de Derechos Humanos. Relatoría Especial para la Libertad de Expresión. Informe Anual de la Relatoria Especial para la Libertad de Expressión, 2015. Disponível em: <http://www.oas.org/es/cidh/expresion/docs/informes/anuales/informeanual2015rele. pdf> Acesso em: 10 out. 2019. p. 375. 
SILVA, Bruna Marques da. Discursos intolerantes (ou discursos de ódio?) de parlamentares contra grupos sociais minoritários no Brasil. Revista Eletrônica Direito e Política, Programa de PósGraduação Stricto Sensu em Ciência Jurídica da UNIVALI, Itajaí, v.15, n.3, 30 quadrimestre de 2020. Disponível em: www.univali.br/direitoepolitica - ISSN 1980-7791

sedimenta, por vezes, a possibilidade de que os grupos sociais destinatários sejam classificados como responsáveis por determinadas situações sociais negativas, no momento em que suas características identitárias sejam utilizadas como justificativa ou razão para tanto. Nesse viés, Soares registra que manifestar-se contra direitos já garantidos ou opor-se a reivindicações de grupos minoritários é diferente de expor tais posicionamentos a base de discursos de ódio. ${ }^{35} \mathrm{O}$ autor esclarece:

\begin{abstract}
Pensemos em alguém que simplesmente afirme que a redução da menoridade penal é necessária, pois "na periferia só tem delinquente e vagabundo, negras e negros menores de idade, que continuamente alegam que são crianças, enquanto se sabe que esses macacos são já bem conscientes de seus atos $e$, por isso, merecem ser castigados penalmente como adultos". A postura política que até então ostentava uma aparência de legitimidade agora ganha contornos distintos ao expressar de maneira cristalina o móvel da ação indicada, isto é, a razão psíquica última da proposta defendida, cuja base é o preconceito, o racismo e a segregação. ${ }^{36}$
\end{abstract}

Sob os argumentos Soares, se tais manifestações são articuladas com sustento em expressões de ódio, estas podem prejudicar o debate democrático e problematizar ainda mais o direito à igualdade e os limites ao exercício do direito à liberdade de expressão. ${ }^{37}$ Em complementação, Schäffer, Leivas e Santos aduzem que o discurso de ódio, nestas circunstâncias, fomenta não apenas uma desconfiança em relação ao grupo social alvo do discurso pela população, mas um legítimo estímulo à intolerância e ao ódio fundados na pertença identitária de coletividades que, geralmente, representam grupos sociais minoritários. ${ }^{38}$

\footnotetext{
35 SOARES, Alessandro. Direitos humanos e decoro parlamentar: sobre a possibilidade de cassação de mandato por discurso de ódio. Revista DIREITO UFMS. v3. n.2 jul./dez, p. 123-152, Mato Grosso do Sul, 2017.
}

36 SOARES, Alessandro. Direitos humanos e decoro parlamentar: sobre a possibilidade de cassação de mandato por discurso de ódio. Revista DIREITO UFMS. v3. n.2 jul./dez, p. 123-152, Mato Grosso do Sul, 2017. p. 131.

37 SOARES, Alessandro. Direitos humanos e decoro parlamentar: sobre a possibilidade de cassação de mandato por discurso de ódio. Revista DIREITO UFMS. v3. n.2 jul./dez, p. 123-152, Mato Grosso do Sul, 2017.

38 SCHÄFER, Gilberto; LEIVAS, Paulo Gilberto Cogo; SANTOS, Rodrigo Hamilton dos. Discurso de ódio: da abordagem conceitual ao discurso parlamentar. Revista de informação legislativa, $v$. 52, n. 207, p. 143-158, jul./set. 2015. Disponível em: <http://www12.senado.leg.br/ril/edicoes/52/207/ril_v52_n207_p143>. Acesso em: 06 out. 2019. 
SILVA, Bruna Marques da. Discursos intolerantes (ou discursos de ódio?) de parlamentares contra grupos sociais minoritários no Brasil. Revista Eletrônica Direito e Política, Programa de PósGraduação Stricto Sensu em Ciência Jurídica da UNIVALI, Itajaí, v.15, n.3, 30 quadrimestre de 2020. Disponível em: www.univali.br/direitoepolitica - ISSN 1980-7791

Pontua Lenz, nessa perspectiva, que os discursos considerados de ódio proferidos por parlamentares têm demonstrado considerável aumento no Brasil. Entretanto, além do texto constitucional não contar com previsões expressas sobre esta possibilidade, o tema foi pouquíssimo trabalhado pela jurisprudência nesta nomenclatura. Assim, a autora sugere que o conflito entre a imunidade material garantida a parlamentares e possíveis casos de discurso de ódio pode ser trabalhado no sentido de que tais manifestações atingem a dignidade dos grupos sociais destinatários, aprofundando suas discriminações, diante da capacidade de influência dos representantes públicos na sociedade. ${ }^{39}$

Schäfer, Leivas e Santos admitem que esta tarefa é tortuosa, tanto pela essencialidade do direito à liberdade de expressão, quanto pela hipótese de que o debate parlamentar poderia ser reduzido, e enfrentar uma insegurança jurídica. ${ }^{40}$ Sob ótica similar, Paulino salienta a alternativa de que sejam adotados parâmetros para identificar qual tipo de discurso estaria abrangido pela imunidade parlamentar, e qual poderia configurar abuso à garantia, pois reafirma que "[...] a liberdade de expressão parlamentar não é absoluta, mas circunscreve-se ao exercício do mandato ou a atos conexos exercidos em função dele." ${ }^{41}$ Assim, ao aduzir que o texto constitucional determina o dever do decoro parlamentar e dispõe que o abuso de prerrogativas, incluindo a imunidade material, pode constituir uma quebra ao decoro, afirma: "Não estão abrangidas, portanto, manifestações abusivas, incompatíveis com o exercício do mandato político." ${ }^{42}$ Nesse viés, a questão concentraria determinar quais discursos de ódio poderiam constituir uma quebra ao decoro, e quais não.

\footnotetext{
39 LENZ, Fernanda Schirmer. 0 tratamento jurídico da imunidade parlamentar em face do discurso de ódio: Um conflito não previsto pela Constituição de 1988. Curitiba: Editora DRV, 2018.

40 SCHÄFER, Gilberto; LEIVAS, Paulo Gilberto Cogo; SANTOS, Rodrigo Hamilton dos. Discurso de ódio: da abordagem conceitual ao discurso parlamentar. Revista de informação legislativa, $v$. 52, n. 207, p. 143-158, jul./set. 2015. Disponível em: <http://www12.senado.leg.br/ril/edicoes/52/207/ril_v52_n207_p143>. Acesso em: 06 out. 2019.

${ }^{41}$ PAULINO, Lucas Azevedo. Imunidade material parlamentar, liberdade de expressão e discurso do ódio: parâmetros para o tratamento jurídico do hate speech parlamentar. In: PEREIRA, Rodolfo Viana (Org.). Direitos políticos, liberdade de expressão e discurso de ódio. Volume I. Belo Horizonte: IDDE, 2018. p. 137-162. Disponível em: https://goo.gl/8SWk2d. Acesso em: 03 out. 2019. p. 157.

42 PAULINO, Lucas Azevedo. Imunidade material parlamentar, liberdade de expressão e discurso do ódio: parâmetros para o tratamento jurídico do hate speech parlamentar. In: PEREIRA, Rodolfo Viana (Org.). Direitos políticos, liberdade de expressão e discurso de ódio. Volume I. Belo
} 
SILVA, Bruna Marques da. Discursos intolerantes (ou discursos de ódio?) de parlamentares contra grupos sociais minoritários no Brasil. Revista Eletrônica Direito e Política, Programa de PósGraduação Stricto Sensu em Ciência Jurídica da UNIVALI, Itajaí, v.15, n.3, 30 quadrimestre de 2020. Disponível em: www.univali.br/direitoepolitica - ISSN 1980-7791

Soares, de igual forma, sustenta que a expressão de discursos de ódio por parlamentares poderia ser enquadrada em uma infringência ao decoro parlamentar, sendo submetido ao processo de cassação de mandato, conforme preconiza o artigo 55, inciso $\mathrm{II}^{43}$ da Constituição Federal, já que o texto constitucional, no caput do artigo 53, não abrange a inviolabilidade política, e sim a civil e penal. Para o autor, ainda que o conceito jurídico de decoro seja amplo e indeterminado, apresentando significado que se modifica ao longo do tempo, a institucionalidade democrática das condutas parlamentares permanece como o principal objetivo a ser resguardado. Assim, esclarecendo que as condutas consideradas indecorosas são aquelas que atingem a honra objetiva e são capazes de desmerecer o parlamento, entende que os casos de posicionamentos políticos que contam com discurso de ódio agridem a democracia como um todo, e podem, portanto, infringir o decoro parlamentar. ${ }^{44}$

A diferença de abordagem, se comparado a Paulino, reside no fato de que Soares concentra a análise na possibilidade de que os discursos de ódio sejam considerados condutas que não correspondem ao dever de decoro parlamentar, enquanto Paulino analisa mais as abrangências da inviolabilidade civil ou penal aos tipos de discurso de ódio ${ }^{45}$. Por fim, cabe registrar que Soares igualmente entende que nem todos os casos de discurso de ódio sejam tratados de forma idêntica:

De toda sorte, como princípio, não se pode abrir mão de apurar e punir qualquer tipo de discurso de ódio parlamentar, do mais tênue e aparentemente inofensivo ao

Horizonte: IDDE, 2018. p. 137-162. Disponível em: https://goo.gl/8SWk2d. Acesso em: 03 out. 2019. p. 157.

43 Artigo 55: "Perderá o mandato o Deputado ou Senador: [...] II - cujo procedimento for declarado incompatível com o decoro parlamentar; [...] $\S 10$ - É incompatível com o decoro parlamentar, além dos casos definidos no regimento interno, o abuso das prerrogativas asseguradas a membro do Congresso Nacional ou a percepção de vantagens indevidas."

${ }^{44}$ SOARES, Alessandro. Direitos humanos e decoro parlamentar: sobre a possibilidade de cassação de mandato por discurso de ódio. Revista DIREITO UFMS. v3. n.2 jul./dez, p. 123-152, Mato Grosso do Sul, 2017.

45 SOARES, Alessandro. Direitos humanos e decoro parlamentar: sobre a possibilidade de cassação de mandato por discurso de ódio. Revista DIREITO UFMS. v3. n.2 jul./dez, p. 123-152, Mato Grosso do Sul, 2017. PAULINO, Lucas Azevedo. Imunidade material parlamentar, liberdade de expressão e discurso do ódio: parâmetros para o tratamento jurídico do hate speech parlamentar. In: PEREIRA, Rodolfo Viana (Org.). Direitos políticos, liberdade de expressão e discurso de ódio. Volume I. Belo Horizonte: IDDE, 2018. p. 137-162. Disponível em: https://goo.gl/8SWk2d. Acesso em: 03 out. 2019. 
SILVA, Bruna Marques da. Discursos intolerantes (ou discursos de ódio?) de parlamentares contra grupos sociais minoritários no Brasil. Revista Eletrônica Direito e Política, Programa de PósGraduação Stricto Sensu em Ciência Jurídica da UNIVALI, Itajaí, v.15, n.3, 30 quadrimestre de 2020. Disponível em: www.univali.br/direitoepolitica - ISSN 1980-7791

mais violento e discriminatório. Não significa, evidentemente, que todo e qualquer discurso de ódio mereça a punição com a perda do mandato nos termos do art. 55, II, da Constituição. Os contextos e as formas como essas manifestações são emitidas podem refletir maior ou menor gravidade e reprovação; por isso, deve-se procurar prever e aplicar penalidades de maneira a garantir a proporcionalidade entre a conduta e a pena. ${ }^{46}$

Schäffer, Leivas e Santos ressaltam, ainda, que é necessário considerar que o Supremo Tribunal Federal vem trabalhando no sentido de perquirir o elo entre a manifestação do parlamentar e o exercício do mandato parlamentar para verificar a abrangência das inviolabilidades civil e penal. Entretanto, não se faz tranquila tal identificação, pois haveria que se estabelecer, de forma segura, que a fala é proveniente da atuação pública, e não a materialização da opinião particular do parlamentar. Por conta disso é que sustentam a análise minuciosa de cada situação, diferenciando, por meio da verificação das circunstâncias do caso, se a fala constitui ideia pessoal, e se é proferida em defesa dos interesses dos eleitores ou da atividade parlamentar como um todo. ${ }^{47}$ Neste ponto, Lenz problematiza que se a imunidade parlamentar não serve de blindagem ao indivíduo, conforme já salientado, os discursos considerados de ódio, que podem causar danos, configurariam situações passíveis de relativizar a imunidade material, a depender do caso concreto. ${ }^{48}$

Este breve levantamento de investigações sobre a manifestação de discursos de ódio por parlamentares elucida alguns argumentos importantes para a reflexão verificação de possíveis enfrentamentos práticos. Na perspectiva da doutrina brasileira apresentada, Soares refere que esses discursos poderiam constituir uma quebra de decoro parlamentar, ou não estariam abrangidos pela prerrogativa da imunidade parlamentar material. Neste aspecto, salienta o

46 SOARES, Alessandro. Direitos humanos e decoro parlamentar: sobre a possibilidade de cassação de mandato por discurso de ódio. Revista DIREITO UFMS. v3. n.2 jul./dez, p. 123-152, Mato Grosso do Sul, 2017. p. 157.

47 SCHÄFER, Gilberto; LEIVAS, Paulo Gilberto Cogo; SANTOS, Rodrigo Hamilton dos. Discurso de ódio: da abordagem conceitual ao discurso parlamentar. Revista de informação legislativa, v. 52, n. 207, p. 143-158, jul./set. 2015. Disponível em: <http://www12.senado.leg.br/ril/edicoes/52/207/ril_v52_n207_p143>. Acesso em: 06 out. 2019.

${ }^{48}$ LENZ, Fernanda Schirmer. 0 tratamento jurídico da imunidade parlamentar em face do discurso de ódio: Um conflito não previsto pela Constituição de 1988. Curitiba: Editora DRV, 2018. 
SILVA, Bruna Marques da. Discursos intolerantes (ou discursos de ódio?) de parlamentares contra grupos sociais minoritários no Brasil. Revista Eletrônica Direito e Política, Programa de PósGraduação Stricto Sensu em Ciência Jurídica da UNIVALI, Itajaí, v.15, n.3, 30 quadrimestre de 2020. Disponível em: www.univali.br/direitoepolitica - ISSN 1980-7791

argumento central de que o parlamentar pode expressar opiniões políticas antagônicas aos direitos das minorias e mesmo assim não as desqualificar ou Ihes conceder um tratamento hostil, com base no pertencimento identitário, a ponto de manifestar um discurso intolerante que configure-se como de ódio, assumindo o risco de gerar dano à coletividade atingida ${ }^{49}$.

Na perspectiva dos entendimentos jurisprudenciais analisados, chama-se atenção a necessária a identificação de que as manifestações se vinculam, ou não, ao exercício do mandato para auferir a abrangência da imunidade parlamentar material. ${ }^{50}$ Além disso, considerando que as imunidades parlamentares não são absolutas, a distinção entre diferentes tipos de discurso de ódio também constituiria um elemento importante segundo Paulino e Soares, principalmente para questionar as medidas jurídicas que podem ser adotadas aos casos de discursos de ódio proferidos em conexão com o mandato. ${ }^{51}$ Dito isso, e partindo da premissa de que discursos intolerantes contra grupos minoritários estão ocorrendo também por parlamentares contra grupos sociais minoritários, o estudo passa a analisar se o Supremo Tribunal Federal vem enfrentando essa temática; caso positivo, como esse panorama está sendo constituído e, ainda, se as manifestações aproximaram-se do conceito adotado neste estudo para discurso de ódio.

49 SOARES, Alessandro. Direitos humanos e decoro parlamentar: sobre a possibilidade de cassação de mandato por discurso de ódio. Revista DIREITO UFMS. v3. n.2 jul./dez, p. 123-152, Mato Grosso do Sul, 2017.

50 BRASIL. Supremo Tribunal Federal. Informativo no 831 - Incitação ao crime de estupro, injúria e imunidade parlamentar. $2016 . \quad$ Disponível em: <http://www.stf.jus.br/portal/informativo/verInformativo.asp?s1=imunidade\%20parlam entar\&numero $=831$ \&pagina $=12 \&$ base $=I N F O>$. Acesso em: 08 out. 2019.

51 SOARES, Alessandro. Direitos humanos e decoro parlamentar: sobre a possibilidade de cassação de mandato por discurso de ódio. Revista DIREITO UFMS. v3. n.2 jul./dez, p. 123-152, Mato Grosso do Sul, 2017. PAULINO, Lucas Azevedo. Imunidade material parlamentar, liberdade de expressão e discurso do ódio: parâmetros para o tratamento jurídico do hate speech parlamentar. In: PEREIRA, Rodolfo Viana (Org.). Direitos políticos, liberdade de expressão e discurso de ódio. Volume I. Belo Horizonte: IDDE, 2018. p. 137-162. Disponível em: https://goo.gl/8SWk2d. Acesso em: 03 out. 2019. 
SILVA, Bruna Marques da. Discursos intolerantes (ou discursos de ódio?) de parlamentares contra grupos sociais minoritários no Brasil. Revista Eletrônica Direito e Política, Programa de PósGraduação Stricto Sensu em Ciência Jurídica da UNIVALI, Itajaí, v.15, n.3, 30 quadrimestre de 2020. Disponível em: www.univali.br/direitoepolitica - ISSN 1980-7791

\section{DISCURSOS INTOLERANTES (OU DISCURSOS DE ÓDIO?) DE PARLAMENTARES CONTRA GRUPOS SOCIAIS MINORITÁRIOS: ANÁLISES JURISPRUDENCIAIS DO SUPREMO TRIBUNAL FEDERAL}

Esta etapa do estudo será realizada a partir da análise de casos tratados no âmbito penal que envolveram discursos intolerantes proferidos por parlamentares contra grupos sociais minoritários, verificando os posicionamentos do Supremo Tribunal Federal e, ainda, se esses discursos se assemelham ao conceito de discurso de ódio referido pela Organização das Nações Unidas para a Educação, a Ciência e a Cultura (UNESCO) ${ }^{52}$. O critério utilizado para escolha dos casos foi restringido, primeiramente, aos casos amplamente divulgados pela mídia, envolvendo Deputados Federais. Considerando que não foi encontrado nenhum resultado por meio da pesquisa dos termos discurso de ódio e imunidade parlamentar na ferramenta de busca de jurisprudência no sítio do Supremo Tribunal Federal ${ }^{53}$, e diante do primeiro critério, foram selecionados aqueles nos quais pelo menos um dos julgadores citou, na fundamentação da decisão, o termo hate speech ${ }^{54}$ ou discurso de ódio, ou que foram enquadrados na tipificação do art. 20 da Lei 7.716/8955. Os casos escolhidos, portanto, foram:

a) Inquérito Penal 3590/DF; b) Inquérito Penal 3862/DF; c) Inquérito Penal 4694.

No Inquérito Penal 3590/DF, o Ministério Público Federal ofereceu denúncia contra o Deputado Federal Marco Antônio Feliciano, diante da suposta prática do delito previsto no artigo 20 da Lei no $7.716 / 98$, devido a publicação na rede

\footnotetext{
52 UNITED NATIONS EDUCATIONAL, SCIENTIFIC AND CULTURAL ORGANIZATION (UNESCO). Countering online hate speech. Iginio Gagliardone. Danit Gal. Thiago Alves. Gabriela Martinez. France: UNESCO, 2015. Disponível em: https://unesdoc.unesco.org/ark:/48223/pf0000233231. Acesso em: 04 ago. 2019.

53 A pesquisa ficou adstrita ao sítio do Supremo Tribunal Federal, por força da prerrogativa de função dos Deputados Federais, artigo $53, \S 1^{\circ}$ da Constituição Federal.

${ }^{54}$ Nomenclatura que comumente é utilizada pela doutrina internacional.

${ }^{55}$ A justificativa para tanto concentra-se no fato de que o HC no 82424/RS (Caso Ellwanger), foi enfrentado por este dispositivo, e considerado um caso emblemático do posicionamento do Supremo Tribunal Federal sobre discurso de ódio. SARMENTO, Daniel. A liberdade de expressão e o problema do "Hate Speech". In: SARMENTO, Daniel. Livres e iguais: estudos de Direito Constitucional. Rio de Janeiro: Lumen Juris, 2006. MEYER-PFLUG, Samantha Ribeito. Liberdade de expressão e discurso do ódio. São Paulo: Editora Revista dos Tribunais, 2009.
} 
SILVA, Bruna Marques da. Discursos intolerantes (ou discursos de ódio?) de parlamentares contra grupos sociais minoritários no Brasil. Revista Eletrônica Direito e Política, Programa de PósGraduação Stricto Sensu em Ciência Jurídica da UNIVALI, Itajaí, v.15, n.3, 30 quadrimestre de 2020. Disponível em: www.univali.br/direitoepolitica - ISSN 1980-7791

social Twitter de manifestação discriminatória contra homossexuais ${ }^{56}$. O Supremo Tribunal Federal, por maioria, decidiu pelo não recebimento da denúncia por considerar o fato atípico, tendo em vista que a redação do artigo 20 da Lei 7.716/89 não menciona especificamente discriminação com base em orientação sexual nas elementares do tipo penal. Apesar dos votos não contarem com um maior aprofundamento sobre os temas, o Ministro Relator Marco Aurélio asseverou que a alegação de vinculação da mensagem com o desempenho do cargo não procederia e o Ministro Luís Roberto Barroso consignou que a expressão representava um caso de discurso de ódio. A decisão transitou em julgado em 24/09/2014. ${ }^{57}$

Inicialmente, salienta-se que esta decisão já foi objeto de considerações por Schäfer, Leivas e Santos e Lenz. Para ambos os autores, a manifestação configura um caso de discurso de ódio. ${ }^{58}$ Registra-se, a título de complementação, que um dos resultados justificado pela expressão ofensiva, o "crime", é o gênero de uma série de condutas típicas que se direcionam ao grupo LGBTI de modo expressivo no Brasil. Segundo o Grupo Gay da Bahia, o Brasil é um país que se destaca por cometer homicídios contra LGBTIs, sendo que em 2017 foram contabilizados 445 homicídios. ${ }^{59}$ Além disso, os Dados Públicos Sobre Violência Homofóbica no Brasil, trabalhados pela Diretoria de Análise de Políticas

\footnotetext{
${ }^{56}$ Registra-se a mensagem: "A podridão dos sentimentos dos homoafetivos levam ao ódio, ao crime, a (sic) rejeição." BRASIL. Supremo Tribunal Federal. Inquérito 3590 DF. Relator: Ministro Marco Aurélio de Melo. Julgado em 12 de agosto de 2014a. Disponível em: <http://portal.stf.jus.br/processos/detalhe.asp?incidente=4352153>. Acesso em: 16 ago. 2018. Fato divulgado pelo G1. Disponível em: <http://g1.globo.com/politica/noticia/2011/03/deputadove-podridao-em-gays-e-diz-que-africanos-sao-amaldicoados.html> Acesso em 20 out. 2019; Terra. Disponível em: <https://www.terra.com.br/noticias/brasil/politica/acusado-de-homofobia-eracismo-feliciano-semeia-polemicas-nocongresso,2f8de89a54bdd310VgnCLD2000000ec6eb0aRCRD.html.> Acesso em: 20 out. 2019.

57 BRASIL. Supremo Tribunal Federal. Inquérito 3590 DF. Relator: Ministro Marco Aurélio de Melo. Julgado em 12 de agosto de 2014a. Disponível em: <http://portal.stf.jus.br/processos/detalhe.asp?incidente=4352153>. Acesso em: 16 ago. 2018.

${ }^{58}$ SCHÄFER, Gilberto; LEIVAS, Paulo Gilberto Cogo; SANTOS, Rodrigo Hamilton dos. Discurso de ódio: da abordagem conceitual ao discurso parlamentar. Revista de informação legislativa, v. 52, n. 207, p. 143-158, jul./set. 2015. Disponível em: <http://www12.senado.leg.br/ril/edicoes/52/207/ril_v52_n207_p143>. Acesso em: 06 out. 2019. LENZ, Fernanda Schirmer. 0 tratamento jurídico da imunidade parlamentar em face do discurso de ódio: Um conflito não previsto pela Constituição de 1988. Curitiba: Editora DRV, 2018.

59 GRUPO GAY DA BAHIA. Mortes violentas de LGBT no Brasil: Relatório 2017. Bahia, 2017. Disponível em: <https://homofobiamata.files.wordpress.com/2017/12/relatorio-2081.pdf> Acesso em: 01 nov. 2019.
} 
SILVA, Bruna Marques da. Discursos intolerantes (ou discursos de ódio?) de parlamentares contra grupos sociais minoritários no Brasil. Revista Eletrônica Direito e Política, Programa de PósGraduação Stricto Sensu em Ciência Jurídica da UNIVALI, Itajaí, v.15, n.3, 30 quadrimestre de 2020. Disponível em: www.univali.br/direitoepolitica - ISSN 1980-7791

Públicas da Fundação Getúlio Vargas (FGV DAPP) a partir da compilação de dados do Disque 100, revelam que durante o ano de 2017 as denúncias mais recorrentes são ameaça, homicídio, lesão corporal e crimes de discriminação por gênero ou orientação sexual. ${ }^{60}$

Em convergência a esse contexto, a definição de discurso de ódio registrada pela UNESCO e referido pela Corte Interamericana de Direitos Humanos abrange expressões discriminatórias, com base na identificação do destinatário como pertencente a determinado grupo social, que podem alimentar um ambiente de prejuízo e intolerância, propiciando um aumento de discriminações, hostilidade e ataques violentos. Somado a isso, conforme já referido, a própria Comissão Interamericana de Direitos Humanos citou expressamente este caso relativo ao Brasil em seu Informe Anual sobre a Liberdade de Expressão de $2015 .{ }^{61}$

Já quanto ao Inquérito Penal no 3862/DF envolvendo os Deputados Federais Alceu Moreira e Luis Carlos Heinze, o Conselho Aty Guassu Guarani Kaoiwa e o Conselho do Povo Terena ofereceram ação penal privada subsidiária da pública, em desfavor de ambos os parlamentares. Os Conselhos sustentaram, na inicial, a prática das condutas previstas no artigo 20 da Lei 7.716/89 contra povos indígenas, bem como a incitação ao ódio e violência ${ }^{62}$, conforme artigo 286 , do Código Penal, por conta de manifestações proferidas em audiência pública a produtores rurais no Município de Vicente Dutra, no Rio Grande do Sul. A queixa-

60 DIRETORIA DE ANÁLISE DE POLÍTICAS PÚBLICAS DA FUNDAÇÃO GETÚLIO VARGAS (FGV DAPP). Dados públicos sobre violência homofóbica no Brasil: 28 anos de combate ao preconceito. [2018?] Disponível em: <http://dapp.fgv.br/dados-publicos-sobre-violenciahomofobica-no-brasil-28-anos-decombate-ao-preconceito/>. Acesso em: 01 nov. 2019.

61 ORGANIZACIÓN DE LOS ESTADOS AMERICANOS (OEA). Comisión Interamericana de Derechos Humanos. Relatoría Especial para la Libertad de Expresión. Informe Anual de la Relatoria Especial para la Libertad de Expressión, 2015. Disponível em: <http://www.oas.org/es/cidh/expresion/docs/informes/anuales/informeanual2015rele. pdf> Acesso em: 10 out. 2019.

62 Registra-se o teor das expressões: Nós os parlamentares, não vamos incitar a guerra, mas lhes digo: se fardem de guerreiros e não deixem um vigarista destes dar um passo na sua propriedade, nenhum. Nenhum. Usem todo o tipo de rede, todo mundo tem telefone, liguem um para o outro imediatamente, reúnam multidões e expulsem do jeito que for necessário. (Deputado Federal Alceu Moreira). Agora eu quero dizer para vocês, o mesmo governo, seu Gilberto Carvalho, também é ministro da presidenta Dilma, e ali estão aninhados quilombolas, índios, gays, lésbicas, tudo o que não presta ali estão aninhados... [...] Tem no palácio do planalto um ministro da Presidenta Dilma, chamado Gilberto Carvalho, que aninha no seu gabinete, índio, negro, sem terra, gays, lésbicas, a família não existe no gabinete desse senhor [...] (Deputado Federal Luis Carlos Heinze). BRASIL. Supremo Tribunal Federal. Inquérito 3862 DF. Relator: Ministro Luís Roberto Barroso. Julgado em 12 de dezembro de 2014b. Disponível em: < http://portal.stf.jus.br/processos/detalhe.asp?incidente=4580694>. Acesso em: 25 ago. 2019. 
SILVA, Bruna Marques da. Discursos intolerantes (ou discursos de ódio?) de parlamentares contra grupos sociais minoritários no Brasil. Revista Eletrônica Direito e Política, Programa de PósGraduação Stricto Sensu em Ciência Jurídica da UNIVALI, Itajaí, v.15, n.3, 30 quadrimestre de 2020. Disponível em: www.univali.br/direitoepolitica - ISSN 1980-7791

crime foi rejeitada por ilegitimidade ativa, sob o fundamento de não haver documento formal que comprovasse a representação das comunidades indígenas pelos respectivos Conselhos. Por conta da questão processual, os votos não concentraram $o$ debate entre imunidade parlamentar e manifestações discriminatórias. ${ }^{63}$

Este caso, além de ter gerado grande repercussão na mídia nacional ${ }^{64}$, também ganhou destaque internacional: o Deputado Federal Luis Carlos Heinze, devido a esta manifestação, ganhou o prêmio de Racista do Ano da ONG Survival International para o Dia Internacional da Eliminação da Discriminação Racial, em 2014. ${ }^{65}$ Além disso, Paulino debruçou análise sobre ambas as manifestações, referindo que a fala de Luis Carlos Heinze estava contextualizada em uma oposição ao governo federal, o que implicaria uma conexão da manifestação com o mandato parlamentar, podendo incidir a inviolabilidade civil e penal assegurada. Já quanto a fala de Alceu Moreira, o autor aduziu que "Embora tenha sido ambígua sua declaração, ele não foi específico nem direto sobre a prática direta de violência e crimes" ${ }^{\prime 66}$, e que apenas o fazendo é que a manifestação não estaria protegida pela liberdade de expressão.

Nesse sentido, no que tange à expressão de Luis Carlos Heinze, mesmo que o termo "não presta" apresente-se como genérico e possa ser considerado subjetivo, conforme observa Paulino ${ }^{67}$, cabe registrar que esta atribuição foi

${ }^{63}$ BRASIL. Supremo Tribunal Federal. Inquérito 3862 DF. Relator: Ministro Luís Roberto Barroso. Julgado em 12 de dezembro de 2014b. Disponível em: < http://portal.stf.jus.br/processos/detalhe.asp?incidente=4580694 >. Acesso em: 25 ago. 2019.

64 G1, disponível em: <http://g1.globo.com/rs/rio-grande-do-sul/noticia/2014/02/em-videodeputado-diz-que-indios-gays-e-quilombos-nao-prestam.html>. Acesso em: 20 out. 2018; Zero Hora, disponível em: <https://gauchazh.clicrbs.com.br/geral/noticia/2014/02/mantenho-o-que-eudisse-diz-deputado-luis-carlos-heinze-sobre-questao-da-terra-no-estado-4417626.html > .

65 SURVIVAL INTERNACIONAL. O lado sombrio do Brasil: Deputado recebe prêmio da Survival, 'Racista do Ano', 2014. Disponível em: <https://www.survivalbrasil.org/ultimas-noticias/10083>. Acesso em: 16 out. 2019.

${ }^{66}$ PAULINO, Lucas Azevedo. Imunidade material parlamentar, liberdade de expressão e discurso do ódio: parâmetros para o tratamento jurídico do hate speech parlamentar. In: PEREIRA, Rodolfo Viana (Org.). Direitos políticos, liberdade de expressão e discurso de ódio. Volume I. Belo Horizonte: IDDE, 2018. p. 137-162. Disponível em: https://goo.gl/8SWk2d. Acesso em: 03 out. 2019.

${ }^{67}$ PAULINO, Lucas Azevedo. Imunidade material parlamentar, liberdade de expressão e discurso do ódio: parâmetros para o tratamento jurídico do hate speech parlamentar. In: PEREIRA, Rodolfo Viana (Org.). Direitos políticos, liberdade de expressão e discurso de ódio. Volume I. Belo Horizonte: IDDE, 2018. p. 137-162. Disponível em: https://goo.gl/8SWk2d. Acesso em: 03 out. 2019. 
SILVA, Bruna Marques da. Discursos intolerantes (ou discursos de ódio?) de parlamentares contra grupos sociais minoritários no Brasil. Revista Eletrônica Direito e Política, Programa de PósGraduação Stricto Sensu em Ciência Jurídica da UNIVALI, Itajaí, v.15, n.3, 30 quadrimestre de 2020. Disponível em: www.univali.br/direitoepolitica - ISSN 1980-7791

dirigida a um grupo social minoritário que se encontra em incessante conflito com o grupo social que recebeu a manifestação. Ou seja, na região onde os discursos foram proferidos há uma incessante luta entre indígenas e nãoindígenas pela disputa de terras reivindicadas como de ocupação tradicional. ${ }^{68}$ Abrangida por estas características também se encontra a fala do Deputado Alceu Moreira, e, apesar de afirmar que "não vamos incitar a guerra", reitera que os produtores rurais devem "se fardar de guerreiros, reunindo multidões e expulsando do jeito que for necessário", referindo-se nitidamente aos povos indígenas que procedem na retomada de territórios em disputa. ${ }^{69}$ Devido a estes dois aspectos, sugere-se que ambos os emissores falavam não apenas de modo intolerante sobre indígenas a um público que está inserido nas situações de conflito com estes povos, mas com certo estímulo ou tolerância a atitudes violentas contra o grupo objeto da fala: a manifestação foi dirigida exatamente ao grupo social (produtores rurais) que atualmente vive uma relação conflituosa com os povos indígenas diante de terras em contendas.

Nesse sentido, de acordo com o conceito utilizado para a configuração de discurso de ódio, mesmo que não seja possível aferir a intenção de ambos os parlamentares e demais elementos probatórios tão somente pelo teor da decisão analisada, esta definição também se estende a expressões de incitação e que alimentam um ambiente prejudicial e de intolerância, sob o entendimento de que podem levar a discriminação, hostilidade ou ataques violentos. ${ }^{70}$

Do que foi dito até aqui, verifica-se que ambas as denúncias relativas aos Inquéritos de n's 3862/DF e 3590/DF não foram recebidas pelo Supremo Tribunal Federal por questões relativas a pressupostos formais, o que impossibilitou a apuração jurídica de mérito relativa a eventual indício de

68 BRAGATO, Fernanda Frizzo; KESTENBAUM, Jocelyn. Atrocidades e conflitos territoriais indígenas: Uma análise de risco no caso Guarani-Kaiowá no Estado do Mato Grosso do Sul. Revista Jurídica Consulex, v. 468, p. 28-39, 2016.

69 BRASIL. Supremo Tribunal Federal. Inquérito 3862 DF. Relator: Ministro Luís Roberto Barroso. Julgado em 12 de dezembro de 2014b. Disponível em: < http://portal.stf.jus.br/processos/detalhe.asp?incidente=4580694>. Acesso em: 25 ago. 2019.

70 ORGANIZACIÓN DE LOS ESTADOS AMERICANOS (OEA). Comisión Interamericana de Derechos Humanos. Relatoría Especial para la Libertad de Expresión. Informe Anual de la Relatoria Especial para la Libertad de Expressión, 2015. Disponível em: <http://www.oas.org/es/cidh/expresion/docs/informes/anuales/informeanual2015rele. pdf> Acesso em: 10 out. 2019. 
SILVA, Bruna Marques da. Discursos intolerantes (ou discursos de ódio?) de parlamentares contra grupos sociais minoritários no Brasil. Revista Eletrônica Direito e Política, Programa de PósGraduação Stricto Sensu em Ciência Jurídica da UNIVALI, Itajaí, v.15, n.3, 30 quadrimestre de 2020. Disponível em: www.univali.br/direitoepolitica - ISSN 1980-7791

responsabilidade dos parlamentares no âmbito criminal, bem como as discussões sobre a abrangência da imunidade parlamentar material nas manifestações. 0 Inquérito 4694/DF, de outro lado, oferece certos parâmetros importantes para a análise do panorama jurídico brasileiro a respeito do tema, tendo dado, inclusive, origem aos Informativos nos 913 e 915 intitulados "imunidade parlamentar e liberdade de expressão". ${ }^{71}$

A decisão do Inquérito 4694, nesse sentido, refere-se ao não recebimento da denúncia oferecida pelo Ministério Público Federal em desfavor do à época Deputado Federal Jair Messias Bolsonaro, por declarações proferidas contra grupos sociais minoritários ${ }^{72}$ em palestra ocorrida no Clube Hebraica, Rio de Janeiro/RJ $\mathrm{R}^{73}$. Na fundamentação, o Supremo Tribunal Federal sustentou a não configuração do conteúdo discriminatório das declarações do acusado, que, além de protegidas pela liberdade de expressão, estavam contempladas pela imunidade parlamentar material. ${ }^{74}$

Assim, em relação à ausência de conteúdo discriminatório nas manifestações e abrangência da liberdade de expressão, o Relator Ministro Relator Marco Aurélio utilizou o entendimento sobre discurso discriminatório criminoso ${ }^{75}$ para decidir que as manifestações de Jair Messias Bolsonaro não configuravam o tipo penal de artigo 20 da Lei 7.716/89. Somado a isso, em relação à abrangência da

71 BRASIL. Supremo Tribunal Federal. Inquérito 4694 RS. Relator: Ministro Marco Aurélio. Julgado em 11 de setembro de 2018. Disponível em: <http://portal.stf.jus.br/processos/detalhe.asp?incidente=2052452>. Acesso em: 17 ago. 2018.

72 Dada a extensão das manifestações contidas na denúncia, este estudo não as registrará na íntegra. Para tanto, ver: http://portal.stf.jus.br/processos/downloadPeca. asp?id=15340588165\&ext=.pdf.

73 Fato divulgado pelo G1: https://g1.globo.com/rio-de-janeiro/noticia/mpf-processa-bolsonaropor-ofensas-a-populacao-negra-em-evento-no-rio.ghtml;

Estadão: https://politica.estadao.com.br/noticias/geral,bolsonaro-e-criticado-por-confederacao-israelitaapos-palestra-em-clube-judaico-no-rio,70001728978;

https://veja.abril.com.br/brasil/bolsonaro-e-acusado-de-racismo-por-frase-em-palestra-na-

Veja: hebraica/.

74 BRASIL. Supremo Tribunal Federal. Inquérito 4694 RS. Relator: Ministro Marco Aurélio. Julgado em 11 de setembro de 2018. Disponível em: <http://portal.stf.jus.br/processos/detalhe.asp?incidente=2052452>. Acesso em: 17 ago. 2018.

${ }^{75}$ Esse entendimento já havia sido registrado no julgamento do RHC 134.682/BA, de Relatoria do Ministro Edson Fachin, como baliza à interpretação do dispositivo referido. Ao rejeitar a denúncia, o Ministro Relator afirmou que o conteúdo da declaração não possuía o objetivo de dominação, supressão ou eliminação, sem perfectibilizar o caráter discriminatório. BRASIL. Supremo Tribunal Federal. Recurso Ordinário em Habeas Corpus 134682 BA. Relator: Ministro Edson Fachin. Julgado em 29 de novembro de 2016. Disponível em: < http://portal.stf.jus.br/processos/detalhe.asp?incidente=4988091>. Acesso em: 14 jun. 2019 
SILVA, Bruna Marques da. Discursos intolerantes (ou discursos de ódio?) de parlamentares contra grupos sociais minoritários no Brasil. Revista Eletrônica Direito e Política, Programa de PósGraduação Stricto Sensu em Ciência Jurídica da UNIVALI, Itajaí, v.15, n.3, 30 quadrimestre de 2020. Disponível em: www.univali.br/direitoepolitica - ISSN 1980-7791

imunidade parlamentar material, considerou que as expressões, ainda que intolerantes perante o meio social, estavam ligadas à relação conflituosa entre as demarcações de terras indígenas e quilombolas e o proveito econômico, configurando manifestação política. Além disso, que o convite à palestra teria ocorrido em razão do cargo de Deputado Federal. Ou seja, o nexo de causalidade entre o que foi veiculado e o mandato parlamentar foi entendido como comprovado. ${ }^{76}$

Interessante registrar, ainda, a divergência do Ministro Luís Roberto Barroso, que entendeu que as expressões contra quilombolas configurariam o tipo penal do artigo 20 da 7.716/89, e, mais que isso, que eram casos típicos de discurso de ódio, que não é admitido pelo ordenamento jurídico brasileiro. Especificamente à menção do termo "discurso de ódio" nas fundamentações dos votos, interessante salientar o Ministro Alexandre de Morais afirma a inviolabilidade civil e penal da imunidade parlamentar material pode ser afastada quando, mesmo em conexão com o mandato, as manifestações contarem com excessos abusivos, desvio de finalidade ou, inclusive, discurso de ódio. Segundo o Ministro, as manifestações, ainda que intolerantes e desrespeitosas, não caracterizaram incitação à violência física ou psicológica contra negros, contra refugiados, estrangeiros, o que, aí sim, caracterizaria um discurso de ódio racial, estando além dos limites da inviolabilidade ${ }^{77}$. Nesse sentido:

[...] Ou seja, se, no exercício de sua liberdade de expressão qualificada, o parlamentar sair do script, desvirtuando o exercício de sua liberdade de expressão qualificada, para, por exemplo, realizar ofensas pessoais a eventuais desafetos presentes na plateia ou fora dela, sem nenhum contexto com aquela palestra, ou mesmo veicular discurso de ódio. Nessas hipóteses, a finalidade pretendida não está em consonância com a ratio protetiva das imunidades parlamentares da inviolabilidade. Necessário, para encerrar, fazer a análise das imputações feitas pelo Ministério Público, na denúncia, inclusive citando os minutos em que foram feitas. Analisar se naquelas palavras, opiniões e imputações,

\footnotetext{
76 BRASIL. Supremo Tribunal Federal. Inquérito 4694 RS. Relator: Ministro Marco Aurélio. Julgado em 11 de setembro de 2018. Disponível em: $<$ http://portal.stf.jus.br/processos/detalhe.asp?incidente=2052452>. Acesso em: 17 ago. 2018.

77 BRASIL. Supremo Tribunal Federal. Inquérito 4694 RS. Relator: Ministro Marco Aurélio. Julgado em 11 de setembro de 2018. Disponível em: <http://portal.stf.jus.br/processos/detalhe.asp?incidente=2052452>. Acesso em: 17 ago. 2018.
} 
SILVA, Bruna Marques da. Discursos intolerantes (ou discursos de ódio?) de parlamentares contra grupos sociais minoritários no Brasil. Revista Eletrônica Direito e Política, Programa de PósGraduação Stricto Sensu em Ciência Jurídica da UNIVALI, Itajaí, v.15, n.3, 30 quadrimestre de 2020. Disponível em: www.univali.br/direitoepolitica - ISSN 1980-7791

realizadas no contexto de uma palestra proferida por um deputado federal no exercício das suas funções, ou em razão da função parlamentar, um desvio de finalidade, ou discurso de ódio, que, nesses casos, fugiria da própria ideia constitucional de proteção ao parlamentar. ${ }^{78}$

De acordo com o voto do Ministro Alexandre de Morais, para fins de aferição da imunidade parlamentar material já considerando o nexo de causalidade, haveria uma diferenciação entre discursos intolerantes e discursos de ódio, sendo, estes últimos, entendidos como incompatíveis com a imunidade parlamentar material. ${ }^{79}$

A questão que parece se apresentar, nessa perspectiva, seria a necessidade de verificar quais manifestações podem ser consideradas como discurso de ódio. Ou seja, a problemática de sua definição ou elementos necessários para caracterização jurídica. Retoma-se, assim, o ponto de que a definição de discurso de ódio registrada pela UNESCO e referido pela Corte Interamericana de Direitos Humanos não descarta expressões discriminatórias, com base na identificação do destinatário como pertencente a determinado grupo social, que podem alimentar um ambiente de prejuízo e intolerância, propiciando um aumento de discriminações, hostilidade e ataques violentos ${ }^{80}$.

\section{CONSIDERAÇÕES FINAIS}

A problemática do discurso de ódio, por si só, apresenta desafios ao enfrentamento jurídico doméstico e internacional diante da necessidade de verificação dos possíveis limites ao exercício do direito à liberdade de expressão. Nesse sentido, quando esses casos possivelmente encontram-se conectados a indivíduos que exercem a função parlamentar, a análise há que ser ainda mais

78 BRASIL. Supremo Tribunal Federal. Inquérito 4694 RS. Relator: Ministro Marco Aurélio. Julgado em 11 de setembro de 2018. Disponível em: <http://portal.stf.jus.br/processos/detalhe.asp?incidente=2052452>. Acesso em: 17 ago. 2018.

79 BRASIL. Supremo Tribunal Federal. Inquérito 4694 RS. Relator: Ministro Marco Aurélio. Julgado em 11 de setembro de 2018. Disponível em: <http://portal.stf.jus.br/processos/detalhe.asp?incidente=2052452>. Acesso em: 17 ago. 2018.

80 ORGANIZACIÓN DE LOS ESTADOS AMERICANOS (OEA). Comisión Interamericana de Derechos Humanos. Relatoría Especial para la Libertad de Expresión. Informe Anual de la Relatoria Especial para la Libertad de Expressión, 2015. Disponível em: <http://www.oas.org/es/cidh/expresion/docs/informes/anuales/informeanual2015rele. pdf> Acesso em: 10 out. 2019. 
SILVA, Bruna Marques da. Discursos intolerantes (ou discursos de ódio?) de parlamentares contra grupos sociais minoritários no Brasil. Revista Eletrônica Direito e Política, Programa de PósGraduação Stricto Sensu em Ciência Jurídica da UNIVALI, Itajaí, v.15, n.3, 30 quadrimestre de 2020. Disponível em: www.univali.br/direitoepolitica - ISSN 1980-7791

minuciosa e detalhada, com respeito máximo aos direitos humanos e as garantias asseguradas constitucionalmente.

A partir da análise jurisprudencial, foi possível verificar, de forma principal, que discursos intolerantes proferidos por parlamentares contra grupos sociais minoritários estão sendo judicializados, sendo que, nesses casos, o alcance da garantia da imunidade parlamentar material permanece conectado ao exercício da função parlamentar. Além disso, a pesquisa também aponta que os discursos intolerantes analisados tendem a aproximar-se do conceito jurídico de discurso de ódio referido pela Organização das Nações Unidas para a Educação, a Ciência e a Cultura (UNESCO), considerado pela UNESCO como a definição que contempla a maioria das considerações sobre a configuração deste fenômeno.

A título complementar e limitada ao objeto da pesquisa, salienta-se a constatação de que pouquíssimas considerações sobre a doutrina do hate speech foram registradas nos fundamentos das decisões. Aponta-se, ainda, os importantes registros das orientações do direito internacional dos direitos humanos quando aduzem que representantes da população, em alta posição social, além do compromisso de não exercer o direito à liberdade de expressão em confronto com outros direitos de igual status, possuem o dever de contribuir para desmantelar estereótipos; agir em prol da superação das condições de vulnerabilidade de grupos minoritários; e não agir contra a confiança destes grupos na própria democracia.

\section{REFERÊNCIAS DAS FONTES CITADAS}

BRAGATO, Fernanda Frizzo; KESTENBAUM, Jocelyn. Atrocidades e conflitos territoriais indígenas: Uma análise de risco no caso Guarani-Kaiowá no Estado do Mato Grosso do Sul. Revista Jurídica Consulex, v. 468, p. 28-39, 2016.

BRASIL. Constituição da República Federativa do Brasil de 1988. Disponível

em: <http://www.planalto.gov.br/ccivil_03/constituicao/constituicao.htm>. Acesso em: 14 ago. 2019.

BRASIL. Superior Tribunal de Justiça. Recurso Especial 1642310 DF. Relatora Ministra Nancy Andrighi. Julgado no dia 15 de agosto de 2017. Disponível em: <https://ww2.stj.jus.br/processo/pesquisa/?aplicacao=processos.ea\&tipoPesquis $\mathrm{a}=\mathrm{ti}$ poPesquisaGenerica\&termo=REsp\%201642310>. Acesso em: 08 out. 2019. 
SILVA, Bruna Marques da. Discursos intolerantes (ou discursos de ódio?) de parlamentares contra grupos sociais minoritários no Brasil. Revista Eletrônica Direito e Política, Programa de PósGraduação Stricto Sensu em Ciência Jurídica da UNIVALI, Itajaí, v.15, n.3, 30 quadrimestre de 2020. Disponível em: www.univali.br/direitoepolitica - ISSN 1980-7791

BRASIL. Supremo Tribunal Federal. Informativo no 831 - Incitação ao crime de estupro, injúria e imunidade parlamentar. 2016. Disponível em: <http://www.stf.jus.br/portal/informativo/verInformativo.asp?s1=imunidade\%2 Oparlam entar\&numero $=831$ \&pagina $=12 \&$ base $=$ INFO $>$. Acesso em: 08 out. 2019.

BRASIL. Supremo Tribunal Federal. Inquérito 3590 DF. Relator: Ministro Marco Aurélio de Melo. Julgado em 12 de agosto de 2014a. Disponível em: $<$ http://portal.stf.jus.br/processos/detalhe.asp?incidente $=4352153>$. Acesso em: 16 ago. 2018.

BRASIL. Supremo Tribunal Federal. Inquérito 3862 DF. Relator: Ministro Luís Roberto Barroso. Julgado em 12 de dezembro de 2014b. Disponível em: < http://portal.stf.jus.br/processos/detalhe.asp?incidente $=4580694>$. Acesso em: 25 ago. 2019.

BRASIL. Supremo Tribunal Federal. Inquérito 4694 RS. Relator: Ministro Marco Aurélio. Julgado em 11 de setembro de 2018. Disponível em: $<$ http://portal.stf.jus.br/processos/detalhe.asp?incidente $=2052452>$. Acesso em: 17 ago. 2018.

BRASIL. Supremo Tribunal Federal. Recurso Ordinário em Habeas Corpus 134682 BA. Relator: Ministro Edson Fachin. Julgado em 29 de novembro de 2016. Disponível em:

http://portal.stf.jus.br/processos/detalhe.asp?incidente $=4988091>$. Acesso em: 14 jun. 2019.

COUNCIL OF EUROPE. Committee of Ministers. Recommendation $\mathbf{n}^{\circ}$ (97) 20 of the Committee of Ministers to Member States on "Hate Speech". 1997. Disponível em: https://rm.coe.int/CoERMPublicCommonSearchServices/DisplayDCTMContent?do cumentId=0900001680505d5b. Acesso em: 30 jun. 2019.

DIRETORIA DE ANÁLISE DE POLÍTICAS PÚBLICAS DA FUNDAÇÃO GETÚLIO VARGAS (FGV DAPP). Dados públicos sobre violência homofóbica no Brasil: 28 anos de combate ao preconceito. [2018?] Disponível em: <http://dapp.fgv.br/dados-publicos-sobre-violencia-homofobica-no-brasil-28anos-decombate-ao-preconceito/>. Acesso em: 01 nov. 2019.

DJIK, Teun A. Van. Discurso e Poder. 2 ed. São Paulo: Contexto, 2015.

GRUPO GAY DA BAHIA. Mortes violentas de LGBT no Brasil: Relatório 2017. Bahia, $2017 . \quad$ Disponível em: <https://homofobiamata.files.wordpress.com/2017/12/relatorio-2081.pdf> Acesso em: 01 nov. 2019.

LENZ, Fernanda Schirmer. O tratamento jurídico da imunidade parlamentar em face do discurso de ódio: Um conflito não previsto pela Constituição de 1988. Curitiba: Editora DRV, 2018. 
SILVA, Bruna Marques da. Discursos intolerantes (ou discursos de ódio?) de parlamentares contra grupos sociais minoritários no Brasil. Revista Eletrônica Direito e Política, Programa de PósGraduação Stricto Sensu em Ciência Jurídica da UNIVALI, Itajaí, v.15, n.3, 30 quadrimestre de 2020. Disponível em: www.univali.br/direitoepolitica - ISSN 1980-7791

MENDES, Gilmar Ferreira. II - Administração Pública. In: MENDES, Gilmar Ferreira; BRANCO, Paulo Gustavo Gonet. (Org.). Curso de Direito Constitucional. 12 ed. rev. e atual. São Paulo: Saraiva, 2017.

MEYER-PFLUG, Samantha Ribeito. Liberdade de expressão e discurso do ódio. São Paulo: Editora Revista dos Tribunais, 2009.

NACIONES UNIDAS, Asamblea General. Comité para la Eliminación de la Discriminación Racial. Recomendación general no 35: La lucha contra el discurso de odio racista. [S.I.], 26 sept, 2013. Disponível em: <http://www.refworld.org.es/docid/53f4596b4.html>. Acesso em: 22 ou. 2018.

NACIONES UNIDAS, Asamblea General. Promoción y Protección del Derecho a la Libertad de Opinión y de Expresión. [S.I.], 7 sept. 2012. Disponível em: <http://www.un.org/en/ga/search/view_doc.asp?symbol=a/67/357\&Lang=S> Acesso em: 15 out. 2018.

ORGANIZACIÓN DE LOS ESTADOS AMERICANOS (OEA). Comisión Interamericana de Derechos Humanos. Relatoría Especial para la Libertad de Expresión. Informe Anual de la Relatoria Especial para la Libertad de Expressión, $2015 . \quad$ Disponível em: <http://www.oas.org/es/cidh/expresion/docs/informes/anuales/informeanual201 5rele. pdf> Acesso em: 10 out. 2019.

PAULINO, Lucas Azevedo. Imunidade material parlamentar, liberdade de expressão e discurso do ódio: parâmetros para o tratamento jurídico do hate speech parlamentar. In: PEREIRA, Rodolfo Viana (Org.). Direitos políticos, liberdade de expressão e discurso de ódio. Volume I. Belo Horizonte: IDDE, 2018. p. 137-162. Disponível em: https://goo.gl/8SWk2d. Acesso em: 03 out. 2019.

SARMENTO, Daniel. A liberdade de expressão e o problema do "Hate Speech". In: SARMENTO, Daniel. Livres e iguais: estudos de Direito Constitucional. Rio de Janeiro: Lumen Juris, 2006.

SCHÄFER, Gilberto; LEIVAS, Paulo Gilberto Cogo; SANTOS, Rodrigo Hamilton dos. Discurso de ódio: da abordagem conceitual ao discurso parlamentar. Revista de informação legislativa, v. 52, n. 207, p. 143-158, jul./set. 2015. Disponível em: <http://www12.senado.leg.br/ril/edicoes/52/207/ril_v52_n207_p143>. Acesso em: 06 out. 2019.

SOARES, Alessandro. Direitos humanos e decoro parlamentar: sobre a possibilidade

de cassação de mandato por discurso de ódio. Revista DIREITO UFMS. v3. n.2 jul./dez, p. 123-152, Mato Grosso do Sul, 2017.

STRECK, Lênio Luiz; OLIVEIRA, Marcelo Andrade Cattoni de Oliveira; NUNES, Dierli. Seção V. dos Deputados e dos Senadores. Art. 53 - Os deputados e Senadores são invioláveis, civil e penalmente, por quaisquer de suas opiniões, palavras e votos. In: CANOTLHO, J.J. Gomes; MENDES, Gilmar Ferreira; SARLET, 
SILVA, Bruna Marques da. Discursos intolerantes (ou discursos de ódio?) de parlamentares contra grupos sociais minoritários no Brasil. Revista Eletrônica Direito e Política, Programa de PósGraduação Stricto Sensu em Ciência Jurídica da UNIVALI, Itajaí, v.15, n.3, 30 quadrimestre de 2020. Disponível em: www.univali.br/direitoepolitica - ISSN 1980-7791

Ingo Wolfgang. STRECK, Lênio Luiz (coord.). Comentários à Constituição Federal do Brasil. São Paulo: Saraiva/Almedina, 2013.

SURVIVAL INTERNACIONAL. O lado sombrio do Brasil: Deputado recebe prêmio da Survival, 'Racista do Ano', 2014. Disponível em: <https://www.survivalbrasil.org/ultimas-noticias/10083>. Acesso em: 16 out. 2019.

UNITED NATIONS EDUCATIONAL, SCIENTIFIC AND CULTURAL ORGANIZATION (UNESCO). Countering online hate speech. Iginio Gagliardone. Danit Gal. Thiago Alves. Gabriela Martinez. France: UNESCO, 2015. Disponível em: https://unesdoc.unesco.org/ark:/48223/pf0000233231. Acesso em: 04 ago. 2019.

WEBER, Anne. Manual on hate speech. Concil of Europe Publishing, 2009. Disponível em: http://icm.sk/subory/Manual_on_hate_speech.pdf. Acesso em: 30 jun. 2019. 